\title{
Study on the Construction of Law-based Government under China's Rule of Law
}

\author{
Guangxia MAO \\ Department of Public Administration, Donghua University, Shanghai 201620 \\ *Supervisor: Dejun QIN
}

Abstract. On the 15th National Congress of the Chinese Communist Party, the goal of constructing a socialism country under the rule of law was raised, and thus, the national modernization process of China was started. On the 18th National Congress, constructing a law-based government as a new requirement for the realization of an all-round well-off society by 2020 was proposed more unequivocally. The core of "law-based government" lies in emphasizing the legitimacy of the sources of governmental powers and also governmental powers should be subject to the strictly standardized supervision system. It is the basic part of the construction of "country under the rule of law". Building a law-based government is not only a legal but also political issue. Deeply understanding the basic meaning, substantive characteristics, and great significance is a very important part for responding the 18th National Congress of the Chinese Communist Party and enhancing the modernization of the national governance system, but also a key step to early realize the great historical progress of the Chinese dream.

Keywords: China's Rule of Law; Law-based Government; Politics; Modernized Governance

\section{Introduction}

Mayflower Compact was originated from a British ship named with Mayflower that was gradually close to the land of America. There were a total of 102 passengers on the ship. To facilitate the management and establish a constraint foundation for restricting everybody, they signed a treaty on the ship. That convention was known as Mayflower Compact and its significance was comparable with that of British's MAGNA CARTA, the United States' Declaration of Independence, and France's Universal Declaration of Human Rights, etc.

Throughout the Chinese history, China in 1620 was still immersed in the era of the feudal monarchy under the Ming Dynasty. The meaning of the rule of law puts more emphasis on ruling ordinary people but not officials, not even to mention which law is applicable to restrict the government behavior. The ancient Chinese rule of law was serve the ruling class and used as a tool for terrorizing, regulating, and punishing the ordinary people. This phenomenon in nearly three hundred years begun to crumble until "cultural revolution" broke out on November 10, 1965. Extreme individualism, a cult of personality, and the overflow of all sorts of benighted ideologies gave rise to anarchism, thus making social ethos decayed, culture distorted, $\mathrm{f}$ science and technology stagnated, politics disorder, and law repealed. As the Third Plenary Session of the 11th Central Committee of the Chinese Communist Party was held in 1978, China's socialist democracy and legal system construction entered a new historical stage.

On the 15th National Congress of the Chinese Communist Party, the goal of constructing a socialism country under the rule of law was raised, and thus, the national modernization process of China was started. On the 16th 
National Congress, an important task of "advancing administration according to law" was further presented. On the 17th National Congress, a new historical starting point was showed. On the 18th National Congress, constructing a law-based government as a new requirement for the realization of an all-round well-off society by 2020 was proposed more unequivocally.

\section{Analysis on the meanings of the rule of law, government, and law-based government}

To build a law-based government, it is necessary to figure out "what is the rule of law?" and "what is the standard for the rule of law". The rule of law essentially refers to governing rights under the rule of law, and otherwise absolute power will lead to absolute corruption. New Delhi Declaration, passed on the international conference on law in New Delhi in 1959, reflected the general view of society about the "standard for the rule of law": (1) the legislature's function is to create and maintain all conditions of maintaining personal dignity and let all principles in Declaration of the Rights of Man and of the Citizen implemented; (2) to prevent the abuse of administrative power, and also maintain the legal order by an effective government; limit is necessary for the legislative power, and the basic human rights cannot be canceled; (3) legitimate criminal procedures are available for sufficiently protect the right of defendants to defense and the right to an open trial; (4) judicial independence and the freedom of lawyer. Then, what is government and what is a law-based government? In the modern political science, some scholars think that government is to operate the formal systems of maintaining order and promoting collective action at the national level. In this sense, the core function of government is to make, implement and explain law. Also, some scholars think that "government" can be understood from the broad sense and narrow sense. The government in a broad sense is a political entity representing the state based on a country. It can be divided into central government and local government. In terms of the series of state power, it includes three aspects: legislative power, executive power, and judicial power. The government in a narrow sense only gets involved in the administrative power in the series of state power. Briefly, it is to dominate or control other people in the broadest sense.p-;

\section{A multi-angle interpretation on the law-based government under the condition of the socialism}

\subsection{Understanding the law-based government and its normative characteristics in terms of law}

In the implementation of administrative action, administrative departments should drive to solve the old and new problems and contradictions in the economic and social development in accordance with law, and whether the administrative action of government is legal and normative in the process of administration will directly be related to the success or failure of the reform. Therefore, normativity is the primary characteristic of law-based government, and this is specifically because (1) it shall have a sound legislature and ensure it has a law to follow in administration; (2) it shall carry out administration in accordance with conscience law and ensure the scientific and democratic nature of legislation; (3) it shall be supervised by government both externally and internally.

\subsection{Systematically interpreting law-based government and understanding its systemic characteristics}

The rule of law as well as the construction of law-based government is particularly an important aspect of the modernized governance in the national governance system. One striking characteristic is a law system structure made up of constitutional law. On the Fourth Plenary Session of the Communist Party Central Committee, sound legal norm system, efficient law implementation system, strict law supervision system, powerful law guarantee 
system and perfect inner-party laws and regulations system were proposed for the construction of the five major law systems in China. From the social level, the combination of the heteronomy represented by the ruling-by-law thought with the rule of man represented by the rule of virtue constitutes the dual governance system in the social governance, and the relations between government and social organizations have always been related to the healthy development of a country. From the management contents in law-based government, the construction of it is correlated with many aspects. In terms of all parts of law-based government, it is a systematic organization, including the legislative power, administrative power and judicial power in a broad sense. The construction of law-based government protects the administrative efficiency, improves the professionalism of the governance, and reduces the administrative cost.

\subsection{Interpreting law-based government from the perspective of accountability and understanding its accountability characteristics}

The establishment of law-based government aims to regulate the government behavior from the perspective of law and system and promote it to operate openly and barrier the power in cage. In this way, its accountability becomes defined and explicit when the scope of authority of government is more clearly provided.

\subsection{Controlling law-based government from the overall perspective and completing the construction of law-based government}

Since the implementation of the reform and opening-up policy in China, China has made outstanding achievements in the fields such as politics, economy, and culture. Law-based government should always maintain the goal of adhering to the party's leadership, political principles and direction, and important decisions according to the construction of socialist rule of law government proposed on the 18th National
Congress. But the overall objective should not shake. Then, what the Chinese Communist Party and government represent is the most fundamental interest of the masses from the representative of represented class interests. The Party should always keep struggling for accomplishing the interests of the masses. From this point of view, the construction of law-based government is of important global significance in China. Finally, the state's government should not only adhere to the leadership of the Party and represent the fundamental interests of the masses, but also coordinate the relationship between the government and enterprises or social organizations to the maximum from the point of view of government relations.

\section{Accelerating the construction of law-based government and improving the modernization level of governmental management in practice}

In China, the government will also pay attention to the following several points. First, the construction of the government regulations and systems should be strengthened. In the context of the comprehensively deepened reform, it is necessary to continue the government's macroeconomic regulation and control function and improve the requirements for the legitimacy and rationality of governmental performance, for purpose of playing the macroeconomic regulation and control function of government. As the idea of "lawmaking, change and abolishment" and the economic and social development are focused in the field of legislation, the legislation in the key fields should be promoted so as to fill the blank and blind spots of the system. Meanwhile, it is necessary to adhere to scientifically, reasonably making laws and implementing administration in accordance with the existing laws. Second, the segmentation of powers and the standardization of discretionary power performance should be provided. Power results in corruption, while absolute power will give rise to absolute 
corruption. To limit the government behavior, therefore, prohibition should be implemented by law. Specifically, the government's administrative behavior should be truly standardized; the listed power system of government should be fully implemented; the government's administrative discretion should be segmented and standardized; the occurrence of corruption and rent-seeking should be resolutely curbed. Third, the supervision system and accountability system should be perfected, making the construction of law-based government bright along with sunshine. The author thinks that there is supervision necessary in the places with authorization, and otherwise it is embezzlement. The most important in the construction of law-based government is to build a responsible government that is supervised in the application of power, and thus, it should be supervised by the NPC, Chinese people's political consultative conference (CPPCC), judicial department, finance department, audit department, and inspection department, but also the people and the media. Fourth, the construction of law-based government ultimately needs to people to take part in the government.

\section{Conclusions}

Since the 18th National Congress, General Secretary XI Jinping has delivered many important speeches about the legal construction and also proposed many self-evident requirements to the government in the construction of the rule of law. As the foundation of the government management system, the construction of law-based government should consciously comply with the spirit and principle of the rule of law and keep the credibility of the execution of the government as far as possible using the way of rule of law. As the foundation of the government management system, the construction of law-based government should continue actively promoting the reform of the government institutions, the transformation of the government functions, the streamline administration and delegated power, and a clear definition to the rights, responsibilities and obligations of government, so that it can become a good government that is firmly trusted by the masses. As the foundation of the government management system, law-based government should strengthen the construction of governmental regulations and laws and system, to ensure there are laws to abide by. At the same time, it should promote the legislation in the key fields and does not keep blind spots, and always adheres to scientifically, democratically making laws according to the existing laws, so that more people can get involved in the legislative steps in the process of legislation. The construction of law-based government can't be done without people. Therefore, it is necessary to continuously improve the awareness of all-level cadres in the administration as well as the ruling-by-law thoughts and ability according to law. As a result, the important role of ruling-by-law thoughts is practically exerted in the social governance.

\section{References}

[1] Dejun QIN, Aiyang ZHANG. Cultivating the Dominant Spiritual Culture of Chinese Society $[\mathrm{J}]$. Exploration and Free Views, 1999-02.

[2] [UK] David Hume. Selected of Hume Political Essays [M]. Translated by Reheng ZHANG. The Commercial Press, 1993, 59.

[3] [UK] Andrew Heywood. A Core Concept of Political Science [M]. Edited by Puqu WANG. China Renmin University Press, 2014 (07), 10.

[4] Dingjian CAI. A Review of Governing News According to Law [J]. Journal of Law, 1997 (08).

[5] Chengxin ZHOU. Necessary to Establish a Law-based Government for Rule by Law [J]. Theory and Practice of Sezs, 1997, 02: 21-23.

[6] http://baike.baidu.com 